\title{
HIND KUSHT NIVARAN SANGH (INDIAN LEPROSY ASSOCIATION)
}

\section{Annual Report for 1974}

The Annual Report of the Hind Kusht Nivaran Sangh for 1974 makes encouraging reading. The National Leprosy Programme is now geared to rapid development during the 5th Five Year Plan, and the project for its assessment under the Indian Council for Medical Research is now in operation. The Sangh is making its own very important contribution through encouraging coordination between government and voluntary agencies, supporting training courses for physiotherapy technicians, orientation courses for medical officers, health education, rehabilitation and publicity, especially through its own 37 publications. The Sangh took the lead in publicizing World Leprosy Day in India, in association with which 750,000 "leprosy seals" were sold. Leprosy in India is the official organ of the Sangh, and has continued to progress under the Editorship of Dr Dharmendra. The Professor K. C. Sahn Gold Medal for the promotion of research in leprosy has been instituted, with the first award presented to Dr D. K. Job of Christian Medical College and Hospital, Vellore. With over 3 million leprosy sufferers in India, the Sangh has a very important role to play, and we extend greetings and best wishes for its continued prosperity during 1976. 